\title{
Characteristics of the self-regulation of middle school students in Russia during the period of distance learning
}

\section{Características da autorregulação dos alunos do ensino médio na Rússia durante o período de ensino à distância}

\section{Características de la autorregulación de los estudiantes de secundaria en Rusia durante el período de aprendizaje a distancia}

\author{
Natalya N. Novikova ${ }^{1}$ (D), Vita F. Poberezkaya ${ }^{1}$ (D) \\ ${ }^{1}$ Pitirim Sorokin Syktyvkar State University, Syktyvkar, Russia. \\ Corresponding author: \\ Natalya N. Novikova \\ Email: natalya.n.novikova@mail.ru \\ How to cite: Novikova, N. N., \& Poberezkaya, V. F. (2021). Characteristics of the self-regulation of middle school \\ students in Russia during the period of distance learning. Revista Tempos e Espaços em Educação, 14(33), e16755. \\ http://dx.doi.org/10.20952/revtee.v14i33.16755
}

\begin{abstract}
Distance learning can be considered as "self-regulated learning" as it involves students managing their own time, planning their own activities, and taking an active part in interactive communication with classmates and the teacher. The purpose of the study is to identify problems in middle school students' self-regulation of learning activities during the period of distance learning. Based on a comparative analysis of international research, the study identifies the structural components of self-regulation in distance learning including self-organization, goal setting, planning, prediction, self-control, self-assessment, and reflection. The most significant structural component is students' self-organization, which implies making a daily schedule, recording the tasks performed, controlling one's actions in accordance with the daily schedule, as well as independently allocating time for homework. The study is based on a survey of 196 middle school students in the Republic of Komi, Russia. The results of the survey allow identifying the most vulnerable areas of students' selfregulatory activity in the process of planning, organizing, and controlling their time and individual learning activities in a distance learning environment. The practical significance of the study lies in the possibility of using the data obtained to improve the process of distance learning. The materials of the study may be of use to managers, methodologists, and teachers in secondary education in developing methodological recommendations for students regarding the development of selfregulatory skills of middle school students.
\end{abstract}

Keywords: Secondary education. Distance learning. Self-regulation. Diagnostics of students' selfregulatory activity. 


\section{RESUMO}

O ensino à distância pode ser considerado uma "aprendizagem autorregulada", pois envolve os alunos no gerenciamento de seu próprio tempo, no planejamento de suas atividades e na participação ativa na comunicação interativa com os colegas e o professor. O objetivo do estudo é identificar problemas na autorregulação das atividades de aprendizagem de alunos do ensino médio durante o período de EAD. Com base em uma análise comparativa de pesquisas internacionais, o estudo identifica os componentes estruturais da autorregulação no ensino à distância, incluindo auto-organização, definição de metas, planejamento, previsão, autocontrole, autoavaliação e reflexão. O componente estrutural mais significativo é a auto-organização dos alunos, o que implica fazer uma programação diária, registrar as tarefas realizadas, controlar as ações de acordo com a programação diária, bem como alocar de forma independente o tempo para os trabalhos de casa. O estudo é baseado em uma pesquisa com 196 alunos do ensino médio na República de Komi, Rússia. Os resultados da pesquisa permitem identificar as áreas mais vulneráveis da atividade autorregulatória dos alunos no processo de planejamento, organização e controle do tempo e das atividades individuais de aprendizagem em um ambiente de ensino à distância. $O$ significado prático do estudo reside na possibilidade de utilizar os dados obtidos para melhorar o processo de ensino a distância. Os materiais do estudo podem ser úteis para gerentes, metodologistas e professores do ensino médio no desenvolvimento de recomendações metodológicas para alunos com relação ao desenvolvimento de habilidades de autorregulação de alunos do ensino médio.

Palavras-chave: Educação secundária. Ensino à distância. Auto-regulação. Diagnóstico da atividade autorregulatória dos alunos.

\section{RESUMEN}

El aprendizaje a distancia se puede considerar como un "aprendizaje autorregulado", ya que implica que los estudiantes gestionen su propio tiempo, planifiquen sus propias actividades y participen activamente en la comunicación interactiva con los compañeros y el profesor. El propósito del estudio es identificar problemas en la autorregulación de las actividades de aprendizaje de los estudiantes de secundaria durante el período de aprendizaje a distancia. Basado en un análisis comparativo de la investigación internacional, el estudio identifica los componentes estructurales de la autorregulación en el aprendizaje a distancia, incluida la autoorganización, el establecimiento de objetivos, la planificación, la predicción, el autocontrol, la autoevaluación y la reflexión. El componente estructural más significativo es la autoorganización de los estudiantes, que implica hacer un horario diario, registrar las tareas realizadas, controlar las acciones de acuerdo con el horario diario, así como asignar tiempo de forma independiente para las tareas. El estudio se basa en una encuesta a 196 estudiantes de secundaria en la República de Komi, Rusia. Los resultados de la encuesta permiten identificar las áreas más vulnerables de la actividad de autorregulación de los estudiantes en el proceso de planificación, organización y control de su tiempo y actividades de aprendizaje individual en un entorno de aprendizaje a distancia. La trascendencia práctica del estudio radica en la posibilidad de utilizar los datos obtenidos para mejorar el proceso de aprendizaje a distancia. Los materiales del estudio pueden ser de utilidad para los gerentes, metodólogos y maestros de educación secundaria en el desarrollo de recomendaciones metodológicas para los estudiantes con respecto al desarrollo de las habilidades de autorregulación de los estudiantes de la escuela secundaria.

Palabras clave: Educación Secundaria. La educación a distancia. Autorregulación. Diagnóstico de la actividad de autorregulación de los estudiantes.

\section{INTRODUCTION}

In the process of distance learning, students have to regulate their learning independently if they wish to gain an in-depth understanding of the educational material of the school program. Self- 
regulation of learning involves setting the goals of learning, planning and predicting one's activities, assessing one's own efficiency, and allocating possible mistakes and the ways to solve them. In the conditions of distance learning, it is difficult for students to organize and regulate their learning on their own by planning, monitoring, and correcting the learning process.

In Russia and around the world, the COVID-19 pandemic has brought about the mass transition of school education into the distance mode. The results of Russian scientific research indicate that middle school students face great challenges associated with the lack of readiness to carry out learning activities in the online and offline formats and while many of them have some knowledge in the sphere of distance learning, they lack experience in working with digital resources (Nazarov et. al., 2021). Today, there is a need to identify problems in the self-regulation of learning activities of middle school students during the period of distance learning.

\section{LITERATURE REVIEW}

The contemporary goal of distance education is to enable any student to receive an education regardless of their geographic location, health status, various life situations, and time constraints.

In modern science, the concept of "distance education" has not yet been fully established due to the coexistence of such synonymous concepts as "distance learning", "distance education", "distant learning", "tele-education", and more.

The German researcher O. Peters (1983) was one of the first to provide a historical substantiation for the phenomenon of distance education and characterize the emergence of this type of education as a result of the influence of the industrialization process on various spheres of society. According to Peters' conception, this type of learning has several characteristics similar to the process of the production of goods in an industrial society, namely the division of labor (teaching and the development of educational materials is carried out by different individuals), the standardization and mass production (the production of a large number of standardized educational materials for any category of learners), technology (for example, the extensive use of telecommunication and audio technologies in the course of training). On this basis, O. Peters proposes to examine the phenomenon of distance education not within the framework of traditional learning but by analyzing it from the point of the economic theory of industrialization.

D. Sewart (1987) describes distance learning as the process of studying in the distance form, in which students are devoid of immediate assistance and the opportunity to evaluate their results by comparing them to the achievements of others and obtain knowledge, skills, and abilities based on real-life or work experience.

D. Shale (1988) defines distance education as a process of learning, in which the teacher and students are physically apart from each other, moreover, the author emphasizes that it is not an area of education.

D. Keegan (2000) also adheres to the viewpoint that distance education is a strictly specific form of education parallel and complementary to the traditional. D. Keegan distinguishes between three concepts, "distance education", "distance learning", and "distance training", and provides the following definitions:

- distance education is a social institution, the purpose of which is to provide the opportunity (at the international and national scale) to obtain degrees, university diplomas, and certificates to students who are for some reason unable to attend educational centers and study alongside other students;

- distance learning refers to the opportunity for student groups to study together while physically being at a distance (away) from the educational center, i.e. remotely, using electronic technology; 

remotely.

- distance training is the opportunity to obtain professional and technical qualifications

L.R. Porter (1997) also insists on the differential use of these three terms and concepts, arguing that the concept of "distance learning" includes both education and training, while the term "education" covers the programs of primary, secondary and additional education, state and nonstate universities and colleges.

T. Nunan (2000) notes that distance education carries the philosophy of the "flexibility" of education and offers something to each social category that has to do with education.

In M.G. Moore's view (1994), distance education comprises two elements, each of which is measurable. The first element is dialogue, which implies ensuring two-way communication. Some systems of programs offer more two-way communication than others.

The second element is structure, the degree to which the program meets the needs of individual students. Some programs are highly structured, whereas others are more responsive to the needs and goals of individual learners.

Russian science also lacks a unified approach to understanding what distance education is. At the same time, several Russian authors consider distance education as a form of learning.

E.S. Polat (2004) defines distance education as a form of learning in which the interaction between teachers and students is organized remotely and reflects all of the components characteristic of the educational process (the goals, content, methods, organizational forms, learning methods), which are implemented by means of specific Internet technologies and other instruments providing for interactivity.

L.la. Gozman (1999) also considers distance learning to be a form of education in which students study not in a fixed location but remotely, part-time, or in the distance form, i.e. based on the use of new information technology including computer telecommunication.

A.A. Akaian (2001) believes distance learning to be a more democratic form of education, which allows broad segments of society to obtain education regardless of location and presents a complex of technologies that provide students with the main volume of educational material and ensure interactive communication of teachers and students.

I.G. Zhivotovskaia (2002) delineates the concepts of "distance learning" and "virtual learning", and although it has been recognized that both occur at a distance, the author suggests that virtual learning takes place in real time, while distance learning operates through asynchronous communication systems. At the present day, with further improvement and the increasing spread of ICT in all spheres of social life, some researchers tend to view virtual learning as one of the stages of distance learning.

Summarizing all of the above, we can argue that D. Shale (1988) is correct in stating that "distance education is beset with a remarkable paradox - it has asserted its existence, but it cannot define itself".

At present, researchers study the phenomenon of distance learning from different angles, addressing the general approaches to organizing distance learning, the role of teachers in the organization of the new form of education, the psychological aspects of teacher-student interaction in the distance mode, and so on.

In this study, we focus on the problem of the self-regulatory activity of middle school students in the conditions of distance learning. Of interest in this context is the study by Y.C. Kuo, A.E. Walker, K.E.E. Schroder, and B.R. Belland (2014), which characterizes distance learning as more flexible and autonomous compared to traditional learning. The authors argue that distance learning is more student-oriented and requires self-regulation and more frequent use of the self-regulated learning skills on the part of learners.

The same is argued by E. Yukselturk \& S. Bulut (2007), who also add that if students' selfregulation is at a high level, the process of distance learning ends up being more successful. 
Moreover et. al. (2010), as well as Lehmann et. al. (2014) note that if students have difficulty managing their learning processes in distance learning, they are haunted by failure.

Moore \& Kearsley (2012) describe the characteristics of students in distance learning, who can learn anywhere at any time. The authors indicate that these learners take responsibility for planning, managing, and evaluating their learning processes.

All of the examined studies indicate the relevance and significance of the problem of the development of students' self-regulation skills in the process of distance learning.

\section{METHODS}

To identify the problems in the self-regulation of middle school students' learning activity in the period of distance learning, we set the following study objectives:

1. Determining the components of students' self-regulation in the organization of distance learning.

2. Developing the diagnostic materials.

3. Surveying middle school students of the Komi Republic (Russia).

4. Analysis and systematization of diagnostic results.

To determine the components of the self-regulation of students' learning activity in distance learning, we conducted a comparative analysis of the views of various researchers including $\mathrm{L}$. Bol, J.K. Garner (2011), S.E. Morgan (2013), S. Kocdar, A. Karadeniz, A. Bozkurt, K. Buyuk (2018), L. Chmiliar (2011). The results of the comparative analysis are presented in Table 1.

Table 1. Structural components of the self-regulation of students' activity in distance learning

\begin{tabular}{|c|c|c|c|}
\hline L. Bol, J.K. Garner (2011) & S.E. Morgan (2013) & $\begin{array}{l}\text { S. Kocdar, A. Karadeniz, A. } \\
\text { Bozkurt, K. Buyuk (2018) }\end{array}$ & L. Chmiliar (2011) \\
\hline Goal-setting & & Goal-setting & \\
\hline \multicolumn{4}{|l|}{ Planning } \\
\hline \multirow[t]{7}{*}{ Self-control of processes } & Self-checking & & \\
\hline & \multicolumn{3}{|c|}{ Effort regulation/self-regulation of attitude toward learning } \\
\hline & Self-efficacy & & \\
\hline & \multicolumn{2}{|l|}{ Help-seeking } & \\
\hline & $\begin{array}{l}\text { Time and study environment } \\
\text { management }\end{array}$ & $\begin{array}{l}\text { Managing } \quad \text { physical } \\
\text { environment }\end{array}$ & $\begin{array}{l}\text { Time management and } \\
\text { organization }\end{array}$ \\
\hline & & Self-study strategies & $\begin{array}{l}\text { Note-taking, reading, } \\
\text { writing, and memory } \\
\text { strategies }\end{array}$ \\
\hline & & & Executing tests \\
\hline
\end{tabular}

The conducted comparative analysis reveals that researchers distinguish various components within the structure of students' self-regulation in distance learning: goal-setting; planning; self-checking/self-control of processes; effort regulation/self-regulation of attitude toward learning.

However, it should be noted that considerable attention is paid to the component related to the self-organization of activities in the distance learning mode: time and study environment 
management (S.E. Morgan); physical environment management (S. Kocdar, A. Karadeniz, A. Bozkurt, K. Buyuk), time management and organization (L. Chmiliar).

Accounting for previous research, in developing the diagnostic instrument for the present study, we rely on the components of self-organization, goal-setting, planning, prediction, selfcontrol, self-assessment, and reflection.

Each of the components of students' self-regulatory actions in the conditions of distance learning is characterized:

Self-organization - the student creates daily schedules during the period of distance learning, marks the completed tasks in the daily schedule, monitors their actions in accordance with the daily schedule, and independently allocates the time for homework.

Goal-setting - the student can formulate and set the goal of their learning activity and compare the results with it, as well as correct the goal in the mode of distance learning.

Planning - the student can plan their activity independently in the synchronous or asynchronous learning mode, match the action plan to the goal and the steps to be taken, and adjust the action plan in accordance with the step-by-step (or operational) and final results of the activity.

Prediction - the student is aware of the process of working in the online or offline mode by virtue of being able to prognose their actions and foresee the possible "risks" (difficulties) in completing the activity, can predict the variants of events and independently assess their own ability to solve the task considering the changes in the familiar ways of action.

Self-control - the student controls their actions in the distance learning mode, evaluates them, independently allocates and corrects their mistakes, applies the studied rules to the mistakes made, and makes corrections to their activity.

Self-assessment and reflection - in online and offline forms of learning, the student adequately assesses themselves and their participation in the activity, is aware of their actions and carries responsibility for the results, and seeks help when needed (Poberezkaia, Novikova, 2021).

As part of the second objective of the study, we developed the diagnostic material for the study of the level of development of self-regulation in the conditions of distance learning based on students' reflexive self-assessment, which relies on the personal action of self-determination and the regulative action of students' assessment of their activities, as well as the adequacy of understanding of the reasons behind success and failure.

The study uses the survey method. The diagnostic material is comprised of two surveys of middle school students accounting for the format of distance learning (online/offline). The survey includes 37 structured questions, some in open-ended and some in closed form. All survey questions correspond to the structural components of the self-regulation activity and are aimed at assessing the consistency and autonomy in the completion of these actions.

The answer options provided for the questions assessing the level of consistency of actions are "always", "often", "sometimes", and "never". A student answering "always" means that they complete the action systematically. The "often" answer option indicates that the action is not systematic. The answer "sometimes" is understood as situational completion of the activity, and the "never" answer option signifies that the student does not engage in the activity in question.

In questions assessing the autonomy of actions in the course of distance learning, the provided answer options are "me", "classmates", "parents", "teacher", and "was not done". A student's choice of the "me" option indicates that they are completely autonomous in the conditions of distance learning. The "classmates" answer option points to the fact that the action is completed in interaction with classmates. The "parents" and "teacher" answer options imply that a student is unable to complete the action without adults' assistance and their level of autonomy is quite low. The "was not done" answer option refers to the complete lack of independence in a student. 


\section{RESULTS AND DISCUSSION}

The diagnostics of students' self-assessment of the regulation of their activity during distance learning were conducted in January and February of 2021. The survey sample consists of 196 middle school students from the Republic of Komi (Russia) of three different age groups. The age distribution of the survey participants is as follows: $10-12$ years old (5.1\%); $13-15$ years old (55.6\%); $16-18$ years old (39.3\%). The gender composition of the study sample is 135 female $(68.84 \%)$ and 61 male $(31.12 \%)$ respondents.

The conducted survey reveals that in $73.7 \%$ of the cases, distance learning was organized asynchronously (the teachers and students were communicating "with a delay" in time, learning was organized with the use of e-mail, the electronic grade book, and educational resources), and for $26.3 \%$ of the students, the learning was synchronous (the teachers and students interacted in real time via videoconferencing platforms).

Let us more closely examine the study results by each of the components of middle school students' self-regulation in distance learning.

The study of the component of "self-organization" involves assessing the level of students' consistency in creating daily schedules and monitoring their actions in the period of distance learning (Table 2).

Table 2. Number and percentage of students who responded to the questions in the "selforganization" component

\begin{tabular}{|l|l|l|l|l|}
\hline $\begin{array}{l}\text { Survey questions on the "self-organization" } \\
\text { component }\end{array}$ & always & often & sometimes & never \\
\hline $\begin{array}{l}\text { Have you been creating daily schedules for } \\
\text { yourself in distance learning? }\end{array}$ & $\begin{array}{l}41 \\
(20.92 \%)\end{array}$ & $35(17.86 \%)$ & $\begin{array}{l}60 \\
(30.61 \%)\end{array}$ & $60(30.61 \%)$ \\
\hline $\begin{array}{l}\text { Have you been monitoring your actions in } \\
\text { accordance with the daily schedule in distance } \\
\text { learning? }\end{array}$ & $\begin{array}{l}44 \\
(22.45 \%)\end{array}$ & $58(29.59 \%)$ & $\begin{array}{l}49 \\
(25 \%)\end{array}$ & $45(22.96 \%)$ \\
\hline $\begin{array}{l}\text { Have you had time for rest, hobbies, and friends } \\
\text { in distance learning? }\end{array}$ & $\begin{array}{l}99 \\
(50.52 \%)\end{array}$ & $46(23.46 \%)$ & $\begin{array}{l}37 \\
(18.88 \%)\end{array}$ & $14(7.14 \%)$ \\
\hline $\begin{array}{l}\text { Have you been allocating the time for homework } \\
\text { in distance learning? }\end{array}$ & $\begin{array}{l}115 \\
(58.67 \%)\end{array}$ & $48(24.5 \%)$ & $\begin{array}{l}14 \\
(7.14 \%)\end{array}$ & $19(9.69 \%)$ \\
\hline
\end{tabular}

According to the analysis of the collected data, only $20.92 \%$ of the students were systematically creating daily schedules for themselves and $22.45 \%$ were monitoring their actions in accordance with such a plan, while $30.61 \%$ of the students were not planning their day in the course of distance learning. At the same time, it should be noted that quite a great number of students (50.52\%) were systematically planning their time for rest, hobbies, and friends, and $58.67 \%$ were specifically allocating time for homework. The obtained data show that the students did work on their daily schedules, but this work was not always systematic. A significant share of the respondents (30.61\%) report not making daily plans and $22.95 \%$ were not monitoring their activities.

The assessment of the component of "goal-setting" focuses on the actions of setting the goal of learning activity and correlating the goal of the lesson with the results of learning (Table 3 ). 
Table 3. Number and percentage of students who responded to the questions in the "goal-setting" component

\begin{tabular}{|l|l|l|l|l|}
\hline Survey questions on the "goal-setting" component & always & often & sometimes & never \\
\hline $\begin{array}{l}\text { Was the goal of the lesson set at the beginning of } \\
\text { each lesson in distance learning? }\end{array}$ & $\begin{array}{l}39 \\
(19.89 \%)\end{array}$ & $40(20.41 \%)$ & $52(26.53 \%)$ & $65(33.17 \%)$ \\
\hline $\begin{array}{l}\text { Have you been correlating the goal of the lesson with } \\
\text { the outcome of your activity? }\end{array}$ & $\begin{array}{l}19 \\
(9.69 \%)\end{array}$ & $69(35.20 \%)$ & $80(40.82 \%)$ & $28(14.29 \%)$ \\
\hline
\end{tabular}

The analysis of the survey results by this component of self-regulation shows that the share of the students who always set a goal of the lesson reaches only $19.89 \%, 20.41 \%$ do so often, and $33.17 \%$ do not set themselves a goal at the start of the lesson. The results also demonstrate that quite a small number of the students (9.69\%) systematically correlate the goal with the results of their actions, and $35.20 \%$ and $40.82 \%$ of the students do so non-systematically and situationally, respectively.

The component of "planning" is associated with the activities of creating action plans and following them (Table 4).

Table 4. Number and percentage of students who responded to the questions in the "planning" component

\begin{tabular}{|l|l|l|l|l|}
\hline Survey questions on the "planning" component & always & often & sometimes & never \\
\hline $\begin{array}{l}\text { Have you been making action plans for your lessons } \\
\text { in distance learning? }\end{array}$ & $\begin{array}{l}33 \\
(16.84 \%)\end{array}$ & $43(21.93 \%)$ & $38(19.39 \%)$ & $82(41.84 \%)$ \\
\hline $\begin{array}{l}\text { Have you been following your plan in distance } \\
\text { learning? }\end{array}$ & $\begin{array}{l}33 \\
(16.84 \%)\end{array}$ & $50(25.51 \%)$ & $54(27.55 \%)$ & $59(30.10 \%)$ \\
\hline
\end{tabular}

The study shows that $16.83 \%$ of the students plan their course of action systematically and follow this plan. Quite a high number of students (41.84\%) do not plan their activities, and $30.1 \%$ do not follow the plan in distance learning. The acquired data indicate that the action of planning is underdeveloped in quite a lot of students. If the students were making a plan of their actions, they were trying to follow it throughout distance learning, whereas if they were not making action plans or did so non-systematically, following the plan was naturally difficult or impossible.

The next questions address the criterion of "prediction". This criterion indicates the students' awareness of the process of working online by means of the ability to predict their activity, the difficulties that may arise in learning activities, and the variants of events, as well as the ability to independently assess their capabilities (Table 5). 
Table 5. Number and percentage of students who responded to the questions in the "prediction" component

\begin{tabular}{|l|l|l|l|l|}
\hline Survey questions on the "prediction" component & always & often & sometimes & never \\
\hline $\begin{array}{l}\text { At the beginning of the lesson, when creating your } \\
\text { lesson plan, have you been able to guess where you } \\
\text { might have had difficulties, and did your expectations } \\
\text { match the outcome of your activities? }\end{array}$ & $15(7.65 \%)$ & $43(21.94 \%)$ & 63 \\
$(32.14 \%)$ & $75(38.27 \%)$ \\
\hline $\begin{array}{l}\text { Have you been preparing for lessons in advance } \\
\text { (looking through the materials before the lesson)? }\end{array}$ & $18(9.18 \%)$ & $40(20.41 \%)$ & $51(26.02 \%)$ & $87(44.39 \%)$ \\
\hline
\end{tabular}

The analysis of students' answers reveals a correlation between the ability to assume the "difficulties" in the results of the activities and the preparation for the lesson in advance. $38.27 \%$ of the respondents were not making predictions regarding the upcoming difficulties in distance learning and $44.39 \%$ were not preparing for studying new lesson topics. The majority of the students were rarely prognosing their activities and, therefore, were just as unsystematic in preparing for lessons on new topics.

An important criterion of self-regulation is self-control, which involves a student controlling and assessing their learning activities in distance learning and independently allocating and correcting the mistakes made (Table 6).

Table 6. Number and percentage of students who responded to the questions in the "self-control" component

\begin{tabular}{|l|l|l|l|l|}
\hline Survey questions on the "self-control" component & always & often & sometimes & never \\
\hline $\begin{array}{l}\text { Have you been correlating your actions with the plan } \\
\text { in distance learning? }\end{array}$ & $\begin{array}{l}25 \\
(12.76 \%)\end{array}$ & $37(18.88 \%)$ & $\begin{array}{l}69 \\
(35.20 \%)\end{array}$ & $65(33.16 \%)$ \\
\hline $\begin{array}{l}\text { Have you been noticing your mistakes in assignments } \\
\text { in distance learning? }\end{array}$ & $\begin{array}{l}28 \\
(14.29 \%)\end{array}$ & $60(30.61 \%)$ & $\begin{array}{l}86 \\
(43.88 \%)\end{array}$ & $22(11.22 \%)$ \\
\hline $\begin{array}{l}\text { Have you been able to independently find and correct } \\
\text { your mistakes in distance learning? }\end{array}$ & $\begin{array}{l}16 \\
(8.16 \%)\end{array}$ & $40(20.41 \%)$ & $\begin{array}{l}80 \\
(40.82 \%)\end{array}$ & $60(30.61 \%)$ \\
\hline $\begin{array}{l}\text { Have you been able to explain your mistakes in } \\
\text { assignments? }\end{array}$ & $70(35.71 \%)$ & $45(22.96 \%)$ & $51(26.02 \%)$ & $30(15.31 \%)$ \\
\hline
\end{tabular}

The obtained data reveal only $12.76 \%$ of the respondents systematically checking their actions with the plan, $14.29 \%$ being able to notice their mistakes, and $8.16 \%$ independently allocating and correcting the mistakes made in the tasks. A third of the respondents report checking with the learning action plan and being unable to find their mistakes and correct them.

The results of the study also indicate a relationship between the components of goal-setting, planning, and self-control. If students set a goal, they can not only consciously predict the result of the learning activity in the lesson but also find and correct mistakes on their own. Some students, however, perform the learning actions non-systematically or situationally.

Finally, we consider the criterion of "self-assessment". Developed self-assessment indicates that in the conditions of distance learning, a student can adequately evaluate themselves and their participation in the activity, is aware of the results of their actions and carries responsibility for it, and seeks help when needed (Table 7). 
Table 7. Number and percentage of students who responded to the questions in the "selfassessment" component

\begin{tabular}{|l|l|l|l|l|}
\hline $\begin{array}{l}\text { Survey questions on the "self-assessment" } \\
\text { component }\end{array}$ & always & often & sometimes & never \\
\hline $\begin{array}{l}\text { At the end of a lesson in distance learning, have you } \\
\text { been able to tell what information you had learned } \\
\text { and what had remained challenging? }\end{array}$ & $44(22.45 \%)$ & $74(37.75 \%)$ & $47(23.98 \%)$ & $31(15.82 \%)$ \\
\hline $\begin{array}{l}\text { Have you seen your achievements in distance } \\
\text { learning? }\end{array}$ & $38(19.39 \%)$ & $57(29.08 \%)$ & $62(31.63 \%)$ & $39(19.90 \%)$ \\
\hline $\begin{array}{l}\text { After studying a topic in distance learning, have you } \\
\text { been able to say that you could easily explain this } \\
\text { topic to another person? }\end{array}$ & $19(9.69 \%)$ & $69(35.20 \%)$ & $80(40.82 \%)$ & $28(14.29 \%)$ \\
\hline
\end{tabular}

The survey results show that $22.45 \%$ of the students engage in self-assessment systematically, $19.39 \%$ can see their achievements in distance learning, and only $9.69 \%$ can explain a new topic to another student. Meanwhile, $15.82 \%$ of the students are unable to assess the level of their knowledge at the end of the lesson, $19.90 \%$ do not see their achievements in distance learning, and $14.29 \%$ cannot explain a new topic to another student. The rest of the students perform the main self-assessment learning activities non-systematically or situationally.

As noted above, the autonomy of learning activities of middle school students during distance learning is determined by all structural components of self-regulation (see Table 8 ).

Table 8. Number and percentage of students who responded to questions assessing autonomy in self-regulation of activities in distance learning

\begin{tabular}{|l|l|l|l|l|l|}
\hline $\begin{array}{l}\text { Survey question assessing the } \\
\text { autonomy of self-regulation }\end{array}$ & classmates & parents & teacher & $\begin{array}{l}\text { was } \\
\text { done }\end{array}$ \\
\hline $\begin{array}{l}\text { Who formulated the goal of the } \\
\text { lesson in distance learning? }\end{array}$ & $41(20.92 \%)$ & $\begin{array}{l}5 \\
(2.55 \%)\end{array}$ & $\begin{array}{l}5 \\
(2.55 \%)\end{array}$ & $91(46.43 \%)$ & $54(27.55 \%)$ \\
\hline $\begin{array}{l}\text { Who helped you plan your lesson in } \\
\text { distance learning? }\end{array}$ & $81(41.33 \%)$ & $\begin{array}{l}4 \\
(2.04 \%)\end{array}$ & $\begin{array}{l}5 \\
(2.55 \%)\end{array}$ & $40(20.41 \%)$ & $66(33.67 \%)$ \\
\hline $\begin{array}{l}\text { Who helped you control the } \\
\text { implementation of the lesson plan } \\
\text { in distance learning? }\end{array}$ & $99(50.51 \%)$ & $\begin{array}{l}4 \\
(2.04 \%)\end{array}$ & $13(6.63 \%)$ & $45(22.96 \%)$ & $35(17.86 \%)$ \\
\hline $\begin{array}{l}\text { Who helped you master } \\
\text { challenging topics in distance } \\
\text { learning? }\end{array}$ & $86(43.88 \%)$ & $\begin{array}{l}17 \\
(8.67 \%)\end{array}$ & $22(11.22 \%)$ & $43(21.94 \%)$ & $28(14.29 \%)$ \\
\hline
\end{tabular}

The obtained results indicate that $20.92 \%$ of the students tried to set a goal of the lesson independently in distance learning, $41.33 \%$ report planning their activities during the lesson, $50.51 \%$ plan their learning activity, and $43.88 \%$ master the main content of lessons on their own.

Quite a low share of the students (2.04-8.67\%) are found to carry out the main selfregulation activities in interaction with their classmates. The role of parents in the regulation of students' activity in distance learning in terms of goal-setting, planning, and control of the main actions is also a minor one (2.55-11.22\%). Meanwhile, the role of the teacher in students' selfregulation of activity in distance learning is quite substantial. In $46.43 \%$ of the cases, the teacher was the figure helping students set the goal of the lesson, $20.41 \%$ of the answers indicate that the students were referring to the teacher's assistance in planning their actions, in $22.96 \%$ of the cases 
the teacher was helping students control their actions, and $21.94 \%$ of the respondents report the teacher helping them master challenging topics. The results of the study thus demonstrate the productive interaction between teachers and students in the period of distance learning and point to little autonomy of students in the self-regulation of activity.

\section{CONCLUSION}

The results of the survey of middle school students in the Republic of Komi (Russia) reveal a correlation between the levels of development of all components of students' self-regulation of learning activity during the distance learning period. It is found that in the context of distance learning, a high level of development of self-organization in middle school students is associated with high levels of regulation of activity in the process of goal-setting, planning, prediction, selfcontrol, self-assessment, and reflection. A correlation is also detected between the systemic nature and autonomy of middle school students' learning activities in the course of distance learning.

It is worth noting that self-organization, self-regulation, and autonomy in performing learning actions play a decisive role in distance learning. Students have difficulties self-regulating their activities, and teachers face the need to create optimal conditions for the development of the necessary components of self-regulation at all stages of the distance learning process. Leaflets and instructions for students, as well as interactive forms of communication, will support students and increase their autonomy and activity in the period of distance learning.

The results of the conducted study can serve as an important foundation for further research in the sphere of organizing distance learning with middle school students and the development of methodological recommendations for teachers. What appears to be the most promising continuation of this study is surveying with students in other regions of Russia with additional quantitative analysis methods.

Authors' Contributions: Novikova, N. N.: conception and design, acquisition of data, analysis and interpretation of data, drafting the article, critical review of important intellectual content. Poberezkaya, V. F.: conception and design, acquisition of data, analysis and interpretation of data, drafting the article, critical review of important intellectual content. All authors have read and approved the final version of the manuscript.

Ethics Approval: Not applicable.

Acknowledgments: The study is funded by the Russian Foundation for Basic Research under the scientific project 1929-14169 "Development of regulatory and communicative learning activities of students in the conditions of the digitalization of general and additional education".

\section{REFERENCES}

Akhaian, A.A. (2001). Virtualnyi pedagogicheskii vuz: Teoriia stanovleniia. [Virtual pedagogical university: The theory of development.] Saint Petersburg: Korifei.

Barnard-Brak, L., Lan, W.Y., Paton, W.O. (2010). Profiles in self-regulated learning in the online learning environment. International Review of Research in Open and Distance Learning, 11(1), 61-80.

Bol, L., Garner, J.K. (2011). Challenges in supporting self-regulation in distance education environments. Journal of Computing in Higher Education, 23(2), 104-123. http://dx.doi.org/10.1007/s12528-011-9046-7

Chmiliar, L. (2011). Self-Regulation Skills and the PostSecondary Distance Learner, International Conference on Education and Educational Psychology (ICEEPSY 2011) Procedia. Social and Behavioral Sciences, 29, 318-321.

Gozman, L.Ia. (1999). Distantsionnoe obuchenie na poroge XXI veka [Distance learning on the verge of the 21st century]. Rostov-on-Don: "Mysl”.

Keegan, D. (2000). Distance Training: Taking Stock at a Time of Change. London: Routledge. 
Kocdar, S., Karadeniz, A., Bozkurt, A., Buyuk, K. (2018). Measuring Self-Regulation in Self-Paced Open and Distance Learning Environments. International Review of Research in Open and Distributed Learning, 19(1). Retrieved from: http://www.irrodl.org/index.php/irrodl/article/view/3255/4503.

Kuo, Y.C., Walker, A.E., Schroder, K.E.E., Belland, B.R. (2014). Interaction, Internet self-efficacy, and self-regulated learning as predictors of student satisfaction in online education courses. Internet and Higher Education, 20, 35-50.

Lehmann, T., Hähnlein, I., Ifenthaler, D. (2014). Cognitive, metacognitive and motivational perspectives on reflection in self-regulated online learning. Computers in Human Behavior, 32, 313-323.

Moore, M.G. (1994). Autonomy and interdependence. The American Journal of Distance Education, 8(2), 15.

Moore, M.G., Kearsley, G. (2012). Distance education: A systems view of online learning. Belmont, CA: WadsworthCengage Learning.

Morgan, S.E. (2013). Self-Regulation and Cultural Orientation on the Academic Achievement of University Students on Distance Education in Kampala, Uganda. Global Journal of Interdisciplinary Social Sciences, 2(4), 1-8. Retrieved from: https://www.longdom.org/articles/self-regulation-and-cultural-orientation-on-the-academic-achievement-ofuniversity-students-on-distance-education-in-kam.pdf

Nazarov, V.L., Zherdev, D.V., Averbukh, N.V. (2021). Shokovaia tsifrovizatsiia obrazovaniia: vospriiatie uchastnikov obrazovatelnogo protsessa [The shock digitalization of education: the perception of participants in the educational process]. Education and science, 23(1), 156-20.

Nunan, T. (2000). Exploring the Concept of Flexibility. In V. Jakupec, \& J. Garrick (Eds.), Flexible learning, human resource and organizational development. (pp. 46-66) London: Routledge.

Peters, O. (1983). Distance teaching and industrial production: a comparative interpretation in outline, in D. Sewart, D. Keegan y B. Holmberg (eds.), Distance Education: International Perspectives. London Croom Helm.

Poberezkaia, V.F., Novikova, N.N. (2021). Diagnostika reguliativnykh universalnykh uchebnykh deistvii obuchaiushchihsia v usloviiakh distantsionnogo obucheniia [Diagnostics of the universal regulatory learning actions of students in distance learning]. Scientific and methodological electronic journal "Koncept", 5(May), 81-96. Retrieved from: http://e-koncept.ru/2021/211033.htm

Polat, E.S., Bukharkina, M.Iu., Moiseeva, M.V. (2004). Teoriia i praktika distantsionnogo obucheniia: Ucheb. posobie dlia studentov vysshikh pedagogicheskikh uchebnykh zavedenii [Theory and practice of distance learning: Textbook for students of pedagogical higher education institutions]. Moscow: "Akademiia".

Porter, L.R. (1997). Creating the Virtual Classroom: Distance Learning with the Internet. New York.

Sewart, D. (1987). Mass Higher Education: Where are We Going? Ortner G. E., Graff K. and Wilmersdorfer H. Distance Education as two-way communication. Essays in Honour of Borje Holmberg, Frankfurt am Main, Berlin, Berne, New York, Paris, Vienna.

Shale, D. (1988). Toward a reconceptualization of distance education The American Journal of Distance Education, 2(3), 25-35.

Shale, D. (1988). Towards a Reconceptualization of Distance Education H Tire. American Journal of Distance Education, $2(3), 25$.

Yukselturk, E., Bulut, S. (2007). Predictors for student success in an online course. Educational Technology \& Society, 10(2), 71-83.

Zhivotovskaia, I.G. (2002). Teoriia i praktika distantsionnogo obucheniia [Theory and practice of distance learning]. Distantsionnoe obuchenie v sovremennom mire. Moscow.

Received: 11 July 2021 | Accepted: 13 September 2021 | Published: 18 November 2021

This is an Open Access article distributed under the terms of the Creative Commons Attribution License, which permits unrestricted use, distribution, and reproduction in any medium, provided the original work is properly cited. 